\title{
Recent Advances in the Study of Enzymes
}

$\mathrm{P}^{\mathrm{R}}$ ROF. R. WILLSTÄTTER, of Munich, and his former pupil, Prof. Waldschmidt-Leitz, of Prague, were the chief speakers at a discussion on recent advances in the study of enzymes, held by the Royal Society on June 16. Most of the contributions were primarily descriptions of particular pieces of work, so that the discussion had no formal unity. It was therefore all the more striking that the proceedings should compose so readily into a set of variations on a group of related themes, indicating quite clearly what are the main problems in current enzyme research. Lack of time cut short the beginnings of an interesting general discussion.

There was general support for Prof. Willstätter's view that an enzyme consists of an active group of definite chemical constitution, with a colloidal carrier. The question of the nature of the active group is closely bound up with the study of enzyme specificity. Prof. Waldschmidt-Leitz described the specificity shown among the peptidases. These enzymes, which have been separated by processes of preferential adsorption and elution from the complex mixtures of proteolytic enzymes found in Nature, are without action on native proteins, but readily hydrolyse polypeptides. They fall into three main groups. The substrate must always have a peptide linkage, but amino-polypeptidases will hydrolyse only those peptides which have a free amino-group, and carboxy-polypeptidases those with a carboxyl group, while di-peptidases will usually attack only dipeptides. The substrate is attached to the enzyme at two points-at the peptide link and at one other group, which varies with the nature of the polypeptidase. The enzyme therefore possesses two combining groups, with chemical affinities for the two groups by which the substrate is held, and so spaced and oriented that they fit in with the structure of the type of polypeptide hydrolysed. This implies rigid chemical structure at the active group of the enzyme. Little is known of the chemical nature of the substrateholding groups in the enzyme, but similarity between the $p H$-activity curves of peptidases and the effect of hydrogen ion concentration on the combination of sugars and peptides suggests that one of the groups may be chemically related to the sugars.

Many other enzymes appear to hold their substrates at two different points. Dr. J. H. Quastel described work he has done in collaboration with Mr. Wheatley on the inhibition of enzymes by a wide range of dyes. The chemical nature of the dye greatly affects the extent of the inhibition, but in general dehydrogenases and urease are sensitive to basic dyes only, while fumarase is also poisoned by acidic dyes. Since the enzyme is protected by the substrate and related compounds from the inhibiting effects of the dyestuffs, it is probable that the toxic action is exerted at the substrate-binding groups. The active groups of dehydrogenases and of urease thus seem to be acidic in nature, while fumarase attaches its substrate at both an acidic and a basic group. Other examples, based on kinetic evidence, were given by Prof. J. B. S. Haldane. Animal lipases were found by Murray, and bacterial dehydrogenases by Woolf, to be inhibited by excess of substrate. The data fit in quantitatively with the hypothesis that in low concentrations the substrate bridges two groups in the enzyme, but in high concentrations inactive complexes tend to be formed, in which each of the enzyme combining groups is linked with a separate molecule of substrate.

Prof. Haldane showed, by a series of examples, that there is a marked correlation between specificity in an enzyme and rigidity of structure in its substrates. Specificity is confined to groups in the substrate molecule which are rigid, such as sugar rings. It never appears to extend to groups which are flexible owing to the possibility of rotation, such as saturated chains. Thus absolute specificity is found among the oxidases, but only a wide group specificity among the enzymes hydrolysing peptides or esters. It seems to follow that specificity depends on the fitting together of rigid structures in enzyme and substrate. The rigidity possessed by systems of condensed rings at once suggests this type of structure for the active group of an enzyme. For three enzymes at least, there is good evidence that the activity is associated with iron combined with condensed pyrrol rings to form a hæmatin compound.

This important recent work on the hæmatin nature of some oxidising enzymes was referred to also by Prof. Willstätter. It has been shown by Hellström and Zeile that highly purified catalase preparations always give the same hæmatin-like spectrum, in an intensity which remains proportional to the catalytic activity through different methods of purification and of inhibition of the enzyme. Similar results have been obtained by Kuhn and his co-workers with the enzyme peroxidase. There was no challenge during the discussion to the conclusion that these two enzymes are hæmatin compounds, but doubts were expressed on the validity of the evidence in the case of a third enzyme, the atmungsferment of Warburg. The evidence here is also spectroscopic, but rather indirect. The enzyme, according to Warburg, functions properly only when the cell is intact, when it activates oxygen and so controls cell respiration. Oxygen uptake is depressed by carbon monoxide, and the inhibition is greater in the dark than in the light. The power of light to reverse the inhibition varies with its wave-length, and when this power is plotted against wave-length a hæmatin. like spectrum is obtained, which Warburg regards as the spectrum of the atmungsferment. 'This identification was contested by Prof. D. Keilin, who described his well-known work on cytochrome. $\mathrm{He}$ recognises three factors in cell respiration: dehydrogenases at which the hydrogen of the meta-

No. 3269, Vor. 129] 
bolites is made available; the oxidase, identical with the indophenol oxidase, at which oxygen is mobilised; and the three hæmatin compounds, cytochrome $a, b$, and $c$, which act as intermediaries, becoming reduced at the dehydrogenases and reoxidised at the oxidase. Prof. Keilin identifies the atmungsferment with the indophenol oxidase, and finds that it differs from typical hæmatin compounds in many of its properties. There is evidence, however, that cytochrome forms a complex with the oxidase, and it is the hæmatin in the cytochrome moiety of this complex which is responsible for the spectrum found by Warburg.

Similar doubts were expressed by Dr. Meldrum from rather a different point of view. Dr. Meldrum has been working with Dr. F. J. W. Roughton on carbonic anhydrase, the enzyme in blood which catalyses the formation of gaseous carbon dioxide from carbonic acid in solution. They have separated it from hæmoglobin, and concentrated it to a very great extent. It is inhibited by cyanides, hydrogen sulphide, and carbon monoxide, and the CO inhibition is reversed by light. These properties in the case of the atmungsferment are regarded by Warburg as proofs of its hæmatin nature. But carbonic anhydrase has no trace of a hæmatin spectrum, so that the validity of Warburg's argument is rendered very doubtful.

So far, the nature of the active group of the enzyme has been considered. Prof. Willstätter summarised the present knowledge of the colloidal carrier, and described recent work on the relation of the enzyme to the living cell. Enzymes are always obtained as complex colloidal solutions, and the nature of the carrier must be inferred by finding what colloids can be dispensed with. Several American workers claim that enzymes are protein in nature-Sherman with amylase, Sumner with urease, and Northrop with pepsin and trypsin. But amylase has been obtained free from protein, and Sumner's crystalline urease preparation is still active after partial hydrolysis with proteolytic enzymes. Protein-free pepsin was obtained so early as 1861. The carriers seemed to vary with the methods by which the enzyme was extracted from the cell. The properties of an enzyme bound to the cell are often unlike those of the same enzyme in solution. The cell-bound or desmo-enzymes are being actively studied in Prof. Willstätter's laboratory, and it has been found, for example, that the desmo-amylase of leucocytes differs from the lyoamylase in that it is inhibited by glycerol and is active in absence of phosphates.

The relation of the enzyme to the cell was considered from another point of view. Sir Frederick Gowland Hopkins, in his opening remarks, referred to the work of Stephenson and Stickland on hydrogenlyase. This is an enzyme, found in $B$. coli communis and other bacteria, which catalyses the breakdown of formic acid into carbon dioxide and free hydrogen. The enzyme appears only in cultures which have been grown on broth containing formates. The substrate thus seems to have the power to influence the growing cell so as to induce in it the formation of a new enzyme. Prof. A.
Harden described a similar phenomenon found with yeast. Normal yeasts ferment only glucose, fructose, and mannose, but the power to ferment galactose may be acquired by yeast grown in a galactose-containing medium. The course of the fermentation appears to be completely normal, the same co-enzyme being required and the same hexose phosphates being formed as in the fermentation of the other sugars. Robison has shown that a mixture of the mono-phosphates of glucose, fructose, and mannose is formed when any one of these sugars is fermented. This suggests that the fermentation takes place through a common intermediate form. Since fructose is fermented the fastest and is the sugar of hexose-diphosphate, this intermediate is probably akin to fructose. The conversion of a sugar into the fermentable form is probably effected by an enzyme or activator specific for the sugar. Such activators may be identical with the hexo-kinase obtained by Meyerhof from yeast, and found by him to enable muscle extracts to use hexoses as a source of lactic acid. The presence of galactose in the growth medium induces the formation in the yeast of a special kinase for galactose.

A distinction between the mode of action of hydrating and oxidising enzymes was brought out in the discussion on the mechanism of enzyme catalysis. Prof. Haldane pointed out that hydrating enzymes show symmetrical $p \mathrm{H}$-activity curves, while dehydrogenases give curves rising from the acid side to a plateau in the alkaline region, as required by Woolf's theory. The discussion on the mechanism of enzymic hydrolysis was disappointing. Prof. Waldschmidt-Leitz regards union between enzyme and substrate at two points as evidence for the two-affinity theory of Euler, according to which the substrate is bound at one group in the enzyme and caused to react by another. But there seemed to be no indication of this difference of function in the two enzyme combining groups, nor was there any discussion on how the water, which is an essential substrate in a hydrolysis, is brought into the reaction. On the other hand, the mechanism of oxidising enzymes gave rise to a lively exchange of opinion. This discussion is being continued in the correspondence columns of Nature, so it is only necessary to give the barest summary here.

Prof. Willstätter gave an account of the theory he put forward in conjunction with Prof. Haber, that the substrates of oxidising enzymes leave the enzyme in the form of free radicles, which initiate chain reactions throughout the medium. Thus ethyl alcohol would form the radicle $\mathrm{CH}_{3}$. $\mathrm{\uparrow} H . \mathrm{OH}$, which interacts with oxygen and a molecule of alcohol to form two molecules of aldehyde and the $\uparrow$

radicle $\mathrm{OH}$. This takes up a hydrogen atom from a molecule of alcohol, regenerating the first radicle, and so the whole cycle is repeated an indefinite number of times. Prof. Haldane criticised this view. It fails to account for the proportionality be. tween enzyme concentration and reaction velocity,

$$
\text { No. 3269, Vou. 129] }
$$


the formation of radicles like $\mathrm{OH}$ which react with many different substances contradicts the facts of enzyme specificity, and the theory cannot account for coupled reactions. Dr. Richter objected to the idea of free radicles, and supported instead the view of Christiansen that there are chains of molecules with abnormally high energy content. Prof. Willstätter replied that such activated molecules would lose their excess energy ,by collisions before they could enter into chemical reaction. H admitted the force of some of Prof. Haldane's arguments, and said that the formulation involving radicles like $\stackrel{\uparrow}{\mathrm{O} H}$ is too simple, and the mechanism must be revised in accordance with the specificity of enzyme action. But whether the chain reaction theory is finally accepted or not, it was made clear by Prof. Haldane that it will be of great service in stimulating fundamental experimental work.

\section{Obituary}

Prof. J. W. Gregory, F.R.S.

T $\mathrm{N}$ the Times of June 14 the brief announcement was made that a wireless message received from Iquitos had been transmitted by Reuters from Lima stating that Prof. J. W. Gregory had been drowned in the Urubamba, near Megantoni Falls in Northern Peru. A subsequent message on the following day confirmed the report and added that Prof. Gregory was drowned by the overturning of his canoe in the rapids of Pongo de Mainique in the River Urubamba. The river at this point is only 24 feet wide, the banks consisting of perpendicular rocks of immense height.

Prof. Gregory left Liverpool six months ago with a small party of which Miss Mackinnon Wood was one, intending to study the geology of Peru with especial reference to earth movements in recent geological times and the connexion between them and earthquakes and volcanic phenomena. Miss Mackinnon Wood was specially interested in the collection of fossils. As no further particulars of the fate of the rest of the party have been received, it may be presumed that they have escaped disaster. The Peruvian Government afforded every facility to the expedition and is stated to have sent two Peruvian geologists to accompany them.

With the death of Prof. Gregory, the most prominent and most widely known British geologist of the present time is removed from the scene. As a writer on geological topics and a lecturer to scientific meetings he had a large public, and his activities as a traveller had made his name well known not in Britain alone but in all parts of the world. He was a ready writer with an easy, fluent style, and was well versed in so many departments of geographical and geological science that his writings cover a vast range of subjects. The mere list of his published volumes is a very impressive one, without taking count of the great series of scientific papers, more than two hundred in number, which came from his pen.

To take a general view of the contributions of a scientific worker so active and so versatile is by no means easy, but we think that Gregory's greatest achievements were in the fields which form a borderland between geology and geography. He will be remembered for his explanation of the rift valleys of Africa, his exposition of the tetrahedral configuration of the earth, his brilliant contribution to the history of the Atlantic and Pacific basins which formed his presidential addresses to the Geological
Society of London, his speculations on the history of valleys and fiords, and the startling hypothesis of the deep-seated and probably volcanic origin of the artesian waters of Central Australia. His mind was constantly occupied with the greater problems of earth structure and history, and his vast erudition gave his opinions a weight which made even those who were most critical of his conclusions treat them with the respect due to profound knowledge and a strikingly original and individual outlook.

Gregory was born in Chelmsford, Essex, in 1864. His father was a wool merchant, and his son assisted him until he was twenty-three years of age. In 1887 he was appointed an assistant in the British Museum, where he served until 1900, when he was appointed professor of geology in the University of Melbourne. He returned from Australia in 1905 to become professor of geology in the University of Glasgow, a post from which he retired on pension in 1929 .

At the British Museum, Gregory was engaged principally in the study of fossil Bryozoa, on which he published three volumes of catalogues well known to specialists, but at an early age the Wanderlust was strong in him. He visited western North America in 1891 and first attracted attention as a traveller and explorer by his journey in British East Africa in 1892-93. This showed clearly the stuff he was made of, as, in spite of discouragement, difficulty, and danger, he executed a notable piece of work, which characteristically formed the foundation of a brightly written book that thoroughly deserved the great popularity with which it was received. Afterwards he visited, on scientific work intent, almost every quarter of the habitable world. In Spitsbergen, 1896 (with Sir Martin Conway), Central Australia and Queensland (1901-4), Cyrenaica (1908), Southern Angola (1912), Rhodesia and India (several times), North America (repeatedly), and Chinese Tibet (along with his son in 1922) he collected geological information and wrote many geographical and geological papers. In 1919 he was awarded the Victoria Medal of the Royal Geographical Society, in 1922 the Gold Medal of the Scottish Geographical Society and the Gallois Medal of the Société Géographique de Paris. These were only a few of the numerous honours which fell to him. He was president of the Geological Society of London (1928-30), and for the second time presided over Section C (Geology) of the British Association at its centenary meeting in London, 1931.

$$
\text { No. 3269, VoL. 129] }
$$

